\title{
Survey and Correlation of Unhygienic Conditions of Agriculture Markets in Punjab
}

\author{
Harpreet Kaur* Manwinder Kaur and Jeevanjot Kaur \\ *PG Department of Agriculture, General Shivdev Singh Diwan Gurbachan Singh Khalsa College, Patiala. 147001 \\ Author for Correspondence: Email-preet20may@gmail.com
}

Received: 20 October 2020/Accepted: 25 November 2020

URL:https://doi.org/10.38112/agw.2020.v08i02.007

\begin{abstract}
The objective of this study was to evaluate the agriculture markets of Punjab. The problem statement was chosen on the basis of pathetic condition of the markets. The market areas are untidy and open. Vegetables and fruits are the necessities of life but the places where these items are sold are pathetic. There are no set norms to put a check on the cleanliness of such markets. To assess the condition of agriculture markets a questionnaire was made. These questionnaires were used for the direct observation as well as opinion of people. For direct observation, the researchers visited the market and filled the data. For opinion of public the questionnaires were distributed among the people visiting various markets and their views were kept secure anonymously. The data was entered into MS Excel. The data so obtained is analysed for any correlation existing among the various factors of cleanliness, waste management, drainage, contamination and facilities like toilet, parking and hand washing. The basic waste managing amenities like smell from garbage (62\%), bins without lid (69\%) and no separation of liquid and solid waste (41\%) were reported.
\end{abstract}

Keywords: Agriculture markets, vegetables, fruits, cleanliness, hygiene, waste management

\section{Introduction}

India is the second largest producer of fruits and vegetables in the world and hence it is known as the fruit and vegetable basket of the world (Kalidas et al., 2014). The fruits and vegetables are necessary for the overall well-being of a person. The daily nutrient requirement includes fruits, grains and vegetables along with some dairy products. These daily necessities must be clean, fit for consumption and nutritious. All these commodities produced come under the category of agricultural produce. The agricultural produce then enters a long supply chain of middlemen from where it reaches to the vendors, mandis, super markets, etc. Most of the consumers buy the regularly used commodities from these markets. The agriculture markets are the main place of buying such commodities for the common man (Klaus., 2005). The agricultural markets include the local vegetable markets, seasonal grain markets, Kisan mandis, fish markets, super markets, etc. In short, all those place where the produce from the farmer's field comes for sale is known as agricultural market.

As discussed earlier, these commodities like vegetables, fruits, grains are the basic necessities of a man to meet the daily food requirements. Have you ever noticed the condition of the places where these commodities are being sold except the super markets which are out of the reach of middle-class families? So, let's just concentrate on those markets from where the majority of the people buy the agricultural commodities. The physical state of these markets is pathetic. There are no set boundaries of the market anyone can enter from anywhere. There is nothing like entry and exit gate. No restrictions on entry of vehicles. People are wandering on their vehicles (bikes, scooters) around the carts. They don't even care that the vehicle emissions will settle down on the fruits and vegetables which can cause illness later. All consumers have the right to expect and demand safe and good quality food.

Hygiene refers to conditions and practices that help to maintain health and prevent the spread of disease (WHO., 2019).Everyone in the market is just busy with their own stuff that they don't bother about the hygiene of the commodities.

The place where markets are set is full of dust and dirt. The garbage is seen scattered on the ground. There are no dustbins for dumping the waste If the dustbins are present at some of the markets then they are not clean. Little do they care to dump the wet and dry waste separately. The vendors don't care about the produce they sell and the buyers don't care about what they consume. This has become a tradition which is being followed from a long 
time. People have started believing that the agricultural markets are supposed to be like this instead of improving their condition over time. The regular condition of the markets is worse but it worsens when rain comes. There is no drainage system to drain the run off. The water remains accumulated in the low-lying area where the mosquitoes develop causing dengue and malaria later on (Abass et al., 2018). These conditions are not good for both the buyers and consumers. Many times, food borne diseases occur. The carts are regularly used for keeping the commodities without any sanitization. The markets like fish market or any meat markets which deals with such raw products which are easily prone to causing infection needs utmost hygiene but their condition is even more dangerous. The vendors sit on road sides and sell the fish. The chopping board and the knives used to cut are never sterilized. These measures are necessary to ensure the safety and suitability of food at all stages of the food chain (WHO., 2019)

\section{Waste Management}

The farm produce is perishable in nature. The commodities have different perishable nature. Some are susceptible to deterioration easily due to high respiration rate like tomato, strawberries, banana and others have somewhat better keeping quality due to low respiration rate like onion, potato, cereals, etc. The leftover produce, decayed, rotten and other stuff like materials used for packaging (newspaper, straw, etc.) are thrown at the market places. The waste generated needs to be disposed-off properly for neat and clean surroundings. For an organized tidy market places dustbins must be installed at suitable distances which has to be cleaned regularly. These bins should be properly covered with lids and free from any kind of stinking or bad or unpleasant odour. The rotted fruits and vegetable produce toxic acids or compounds. Thus, the waste samples must be collected and sent for testing to the laboratories so that any hazard do not take place in future circumstances. Rules have been prescribed to judge the agriculture market conditions using this. (WHO., 2006)

\section{Subject}

The study was conducted to examine the structural built up of the various markets situated in Punjab state of India. In this study, the different type of markets whichever are present in a city or town were taken into account like vegetable markets, grain markets, fish markets, etc. All the fruit and vegetable markets whether they were permanent market or weekly markets were considered for study. The mobile four wheeled vehicles used by the sellers are defined as carts or vending machines here and the persons selling are defined as retailers.
For the study of markets falling under Punjab state the 22 districts were used for covering the whole area. 29 students were selected randomly from the agriculture department of Khalsa College Patiala belonging to different districts and their perspectives were recorded.

The idea was to cover the whole Punjab falling under category of 22 districts. Initially the local markets of Patiala were visited but the people out their refused to participate. Not even a single visitor (consumer) and retailer participated. People visiting the markets were busy in their daily chores. Then randomly students from the agriculture department belonging to different districts of Punjab were selected and they were assigned the duties of providing the data from their near and dear ones for the proposed study. The idea behind this was to get genuine data. In this way 3-4 data sets were collected from each district.

\section{Instruments and Data Collection Techniques}

This research was done to identify the markets which fall short of basic amenities. To conduct this study the guidelines provided by developed countries like Australia, America, etc were followed and the condition of agricultural markets were studied parallel to them.

\section{Data Collection}

For the collection of data two different ways were followed; direct observation and opinion of people. For direct observation as well as opinion of people a questionnaire was used. This questionnaire included open ended as well as close ended questions with categorical and multiple-choice questions. In the direct observation, researchers themselves visited the, markets and answered the various questions. For the opinion of the general consumer the questionnaires were distributed amongst them and their opinions were recorded for further use. A pre-test of the proposed document was conducted on a small sample of randomly selected students from department of agriculture. The direct observation was used for the nearby markets which can be visited easily in the budget. Otherwise the opinion of the consumers was recorded through the distributed questionnaires. This study ensured the anonymity of the people participating in the study. The data was analysed to present overall picture of the infrastructural built up of markets in Punjab.

\section{Instruments}

The questionnaires were used to evaluate the physical structure (lighting, water supply, etc.) as well as food safety points of the markets. The questionnaire was divided into 5 categories totalling 80 items with categorical/multiple choice questions. The categories included basic information about the market to which the consumers were responding (age, gender, location, 
education, reason for purchase), infrastructure and storage of commodities, surrounding conditions with hygiene factor (waste management, sanitization, personal behaviour and health status), policies and law and quality improvement and upgradation. It consists of all the questions which encircle the basic amenities which needs to be changed and all the necessary reforms which must be done to improve the present condition of the agricultural markets. The present study focuses on the infrastructural loopholes of these markets. So, in this study the main focus remains on the conditions of the building structure.

\section{Statistical Analysis}

The information from the questionnaires were entered into Microsoft Excel with double entry for further confidence.

\section{Results and Discussion}

The waste management practices of the agriculture markets were reported pitiful. These practices generally cover solid and liquid waste. In agriculture markets, solid waste considered all the materials like fruits, grain husks, newspaper trashes, straws used for packaging while the liquid waste is any sort of fluid released from pulpy fruits and vegetables or water used for washing, etc (SFM, 2015).

The basic requirement for the waste management is installation of dustbins in the market as per policy of the Indian Govt. In our study the separation of the waste was found to be done by only $41 \%$ people.

Emission of bad odour from stinking garbage came out to be a major issue reported by $62 \%$ of the respondents. The markets were open for easy accession to the public so the belongings were used carelessly like the dustbins which were broken, damaged or present without any lid or cover. The decaying and rotten leftovers were thrown at the market place itself. The garbage remains emit foul smell and produce toxic compounds (such as ethylene and other environmental problem). For the safety of environmental habitat, the waste samples need to be collected timely for testing their positive and negative effect.

In a similar study prepared by CPCB Report, 2013 no city in India can claim 100\% segregation of waste at dwelling unit and on an average only $70 \%$ waste collection is observed, while the remaining $30 \%$ is again mixed up and lost in the urban environment. Out of total waste collected, only $12.45 \%$ waste is scientifically processed and rest is disposed in open dumps.
Vegetable market waste was more prone to fast decay in comparison to grain markets of agriculture. However, the requirements of waste management was observed by governments of countries and have provided some basic polices to be followed, which were generally observed near the inspection times while off inspection times, many markets shown poor conditions according to the on-sight observations. The $90 \%$ of the respondent supported that they have never noticed such practice, while similar have provided guidelines for quick dealing with such situations on daily basis.

According to the presurvey study based on the proposed scale, the falling conditions were observed by $66 \%$ of the respondent. Beside the installation of the dustbins, another important factor was timely emptying and cleaning of the bins. Further, the task of waste management was separation of solid -liquid waste and their disposal management.

Devkota et al. (2014) informed about the utilization of the horticultural waste as an organic manure in the field instead of dumping the waste into the landfills. This practice will not only help in the reduction of waste generation but also it is environment friendly and will aid to the improved conditions of the markets and this was further conveyed in a parallel study by Simko (2000) and Pant and Yami (2008).

Table 1: Waste management in markets

\begin{tabular}{l|c|c|c|c}
\hline \multicolumn{1}{c|}{ Questions } & Yes & n (\%) & No & n (\%) \\
\hline Dustbins in market & 19 & 66.0 & 10 & 34.0 \\
\hline $\begin{array}{l}\text { Separation of solid and } \\
\text { liquid waste }\end{array}$ & 12 & 41.0 & 17 & 59.0 \\
\hline Bad odour from waste & 18 & 62.0 & 11 & 38.0 \\
\hline Dustbins with lid & 9 & 31.0 & 20 & 69.0 \\
\hline Testing of waste samples & 3 & 10.0 & 26 & 90.0 \\
\hline Waste used as manures & 4 & 14.0 & 25 & 86.0 \\
\hline
\end{tabular}

Table 2: Correlation of Waste management

\begin{tabular}{l|l|l|l|l|l|c}
\hline & \multicolumn{1}{c|}{$\mathbf{1}$} & \multicolumn{1}{c|}{$\mathbf{2}$} & \multicolumn{1}{c|}{$\mathbf{3}$} & \multicolumn{1}{c|}{$\mathbf{4}$} & \multicolumn{1}{c|}{$\mathbf{5}$} & $\mathbf{6}$ \\
\hline 1 & 1 & 0.3149 & -0.2681 & 0.32985 & $\begin{array}{l}0.24643 \\
2\end{array}$ & 0.079802 \\
\hline 2 & 0.31492 & 1 & $\begin{array}{l}0.07961 \\
1\end{array}$ & 0.041748 & $\begin{array}{l}0.17440 \\
6\end{array}$ & 0.070014 \\
\hline 3 & -0.2681 & 0.0796 & 1 & 0.063564 & 0.03218 & -0.30559 \\
& & 10858 & & & 7 & \\
\hline 4 & 0.32985 & 0.0417 & 0.06356 & 1 & -0.22787 & 0.520847 \\
\hline 5 & 0.246432 & $\begin{array}{l}0.1744 \\
4\end{array}$ & 0.03218 & -0.22787 & 1 & -0.05217 \\
\hline 6 & 0.079802 & 0.0700 & -0.30559 & 0.520847 & -0.05217 & 1 \\
\hline
\end{tabular}


In the market premises, the sanitation of the basic commodities and the flooring were below the 50\% mark. Agriculture markets don't cover all the products some of them deal with specific products. Some of the Agriculture markets have cemented, tiled flooring, some have kachha flooring and some have mixture of the both.

The hygiene of the market flooring (34\%), carts (38\%) and vending machines (34\%) used for the sale of items, cleanliness of the vendors or sellers (34\%) and toilets $(28 \%)$ were all reported unclean by the majority of the people. Similar results were reported by Alam et al. (2014) who witnessed poor hygiene and sanitation in the fish markets. The hygienic condition of the stalls, floors, spacing were reported below the satisfactory level.

Moreover, the facilities like toilets, cement flooring and the carts used were not up to the mark. The adequate water supply for the washing and cleaning of the markets produce, carts, vending machines and for personal hygiene of the sellers is very essential. In the absence of water supply the sanitation cannot be maintained from as little as hand washing to washing of utensils, carts, etc. which are the integral part of maintain hygiene in the markets. The water availability is very essential in the fish markets in the absence of which markets start stinking due to the odour emitted from fish residues and fish. The $55 \%$ of the respondents reported that even hand washing facilities were not available at some places. Amoah et al. (2006) also reported the lack of clean water for washing. This is a basic practice which should be there. The presence of the proper drainage system in most of the markets was found upto the mark (90\%) which directly showed the presence of sewage and sludge near the market place a little less $(38 \%)$.

The containers and the utensils used were washable reported by $76 \%$ people but were contaminated. Only $55 \%$ people responded in the favour of contamination free utensils which was not a good point because this was not right to play with the health of the consumers. Moreover, this could be elaborated with the fact that at many places adequate water supplies were not available due to which the sellers were not able to wash the utensils which makes the them contaminated.
Table 3: Hygiene practice of the market

\begin{tabular}{l|l|l|l|l}
\hline \multicolumn{1}{c|}{ Questions } & Yes & \% & No & \% \\
\hline Cleanliness of & & & & \\
\hline Floors & 10 & 34.0 & 19 & 66.0 \\
\hline Carts & 11 & 38.0 & 18 & 62.0 \\
\hline Vending machines & 10 & 34.0 & 19 & 66.0 \\
\hline Toilets & 8 & 28.0 & 21 & 72.0 \\
\hline Vendors & 10 & 34.0 & 19 & 66.0 \\
\hline Hand washing facility & 16 & 55.0 & 13 & 45.0 \\
\hline $\begin{array}{l}\text { Sewage and sludge near market } \\
\text { place }\end{array}$ & 11 & 38.0 & 18 & 62.0 \\
\hline $\begin{array}{l}\text { Containers of washable material } \\
\text { Containers free from }\end{array}$ & 22 & 76.0 & 7 & 24.0 \\
contamination & 55.0 & 13 & 45.0 \\
\hline Proper drainage system & 26 & 90.0 & 3 & 10.0 \\
\hline $\begin{array}{l}\text { Labour trained for handling } \\
\text { product }\end{array}$ & 16 & 55.0 & 13 & 45.0 \\
\hline Transporting equipment & 20 & 69.0 & 9 & 31.0 \\
\hline Flying insects present & 22 & 76.0 & 7 & 24.0 \\
\hline Use of sanitizer & 13 & 45.0 & 16 & 55.0 \\
\hline Contamination free food & 18 & 62.0 & 11 & 38.0 \\
\hline
\end{tabular}

The vehicles used for transportation of the commodities were reported clean by $69 \%$ which need to be improved for the better well being of the consumers. Lagerkvist et al. (2013) were of the view that the vegetables also get infected during the transportation from one place to other due to dirty vehicle, road dust, vehicle exhaust, etc. Further, the food was stated contaminated by $38 \%$ persons visiting markets which further can be clubbed with the presence of flying insects present in the market premises conveyed by $76 \%$ people. The flies move from dirt to food and deposit the dust particles on the eatables which remain attached to their feet which act as a major cause for the contamination. Amoah et al. (2011) also reported the presence of houseflies in the vegetable markets along with many other pathogen carrying insects. Not only this, Saeed and Hamid (2010) in another study reported the sellers to be the carriers of bacterium Staphylococcus aureus which can cause serious infections to the consumers. Bordoloi et al. (2014) also stated the similar results in their study on the total plate count in the fish markets. 
Table 4: Correlation of Hygiene Practices

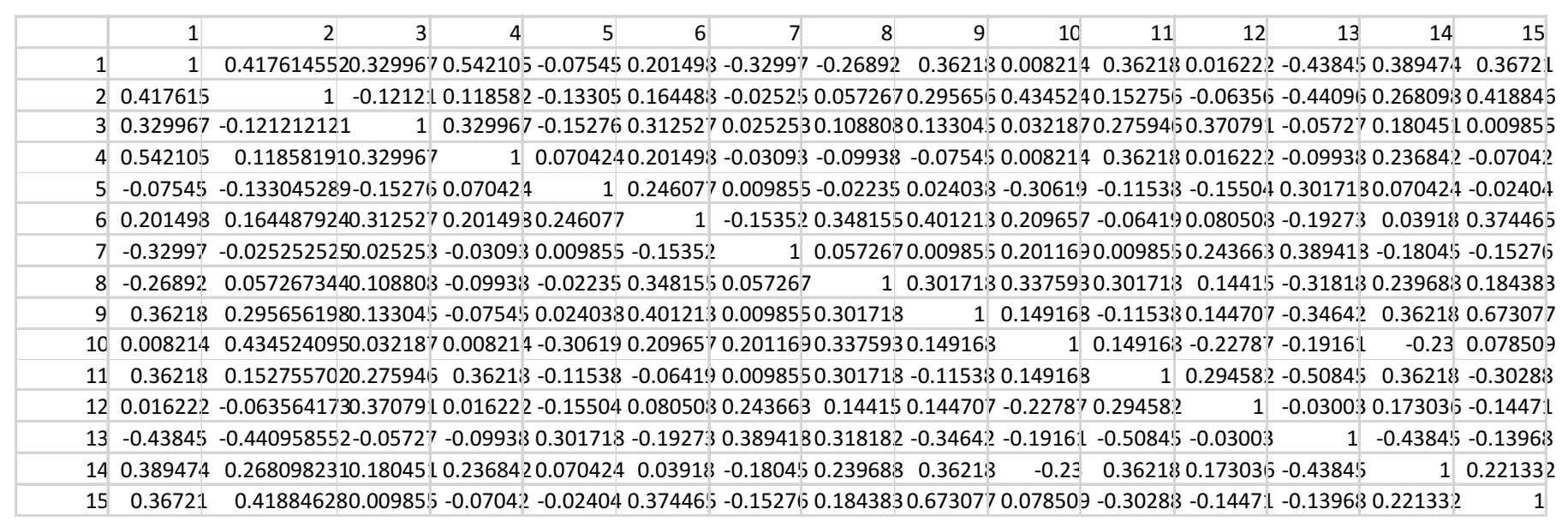

The sellers or the vendors were not provided any training for the handling of the commodities. They learn with the experience only. They were not familiar with international standards which need to be followed. The practices followed by them may also lead to contamination of the food items. Generally, only one person has been seen performing multiple operations like selling of fruit and vegetables, packing and handling the give and take of money. During all these operations, they do not use any sanitizer reported by $45 \%$ of the respondents. Cortese et al.(2016) study in which they also reported that $33 \%$ vendors did not washed hands at all during the day. Even if some of them washed they used only water. Very few reported the use of detergent for cleaning hands. A large number i.e. $95 \%$ vendors performed the give and take of food and money without sanitizing their hands.

\section{Conclusion}

The study points toward the need to improve the existing practices of agriculture markets. Policies and reforms are the major requirements which further needs to be widened and include the basic amenities like training of the food handling workers at the ground level. The cleanliness needs to be maintained and execution of the proper layout of the markets so as to bring some set rules and regulations for the designing of the markets because these are the places from where most of the people buy there necessary food items for daily consumption.

\section{References}

Abass K, Owusu AF and Gyasi RM. 2018. Market vegetable hygiene practices and health risk perceptions of vegetable sellers in urban Ghana. International Journal of Environmental Health Research 7: 78-94

Alam MM, Haque MM and Shikha FH.2014. Studies on public health and hygiene condition of retailers at fish markets in south-central Bangladesh. J Bangladesh Agril Univ. 12(2): 411-418.

Aljaradin M and Persson KM. 2012. Current situation of Municipal Solid Waste Management in Jordan. A glance at the World. The Open Waste Management Journal 5: 28-39

Amoah P, Dreschel P, Abaidoo RC and Ntow WJ. 2006. Pesticide and pathogen contamination of vegetables in Ghana's urban markets. Arch. Environ. Contam. Toxicol. 50(1): 1-6

Amoah P, Keraita B, Akple M, Dreschel P, Abiadoo RC and Konradsen F. 2011. Low-cost options for health risk reduction where crops are irrigated with polluted water in West Africa. Colombo: International Water Management Institute Pp: 116-135

Bordoloi R, Muzaddadi AU and Ganguly S. 2014. Sanitary Condition of Battala Fish Market at Agartala, Tripura and its Public Health Significance. In.t J. Curr. Microbiol. App. Sci. 3(3): 176-181

Central Pollution Control Board. 2013. Status report on municipal solid waste management. Ministry of Environment \& Forests, Parivesh Bhawan, East Arjun Nagar, Delhi - 110 032. Pp: 1-13

Cortese RDM, Veiros MB, Feldmanb C, Cavallia SB. 2016. Food safety and hygiene practices of vendors during the chain of street food production in Florianopolis, Brazil: A cross-sectional study. Food Control 62:178-186

Devkota AR, Dhakal DD, Gautam DM and Dutta DP. 2014.Assessment of fruit and vegetable losses at major wholesale markets in Nepal. International Journal of applied sciences and biotechnology 2(4):559-562

Kalidas K, Jiji S and Sureka M. 2014. Supply chain management in vegetables. Indian Journal of Research $3(2): 315-316$. 
Klaus G. Grunert. 2005. Food quality and safety: consumer perception and demand. European Review of Agricultural Economics 32(3): 369-391

Lagerkvist CJ, Hess S, Okello J, Hansson H and Karanja N. 2013. Food health risk perceptions among consumers, farmers, and traders of leafy vegetables in Nairobi. Food Policy 38: 92-104

Pant SR and Yami KD. 2008. Selective Utilization of Organic Solid Waste by Earthworm. Nepal Journal of Science and Technology 9: 99-104

Rais M and Sheoran A. 2015. Scope of Supply Chain Management in Fruits and Vegetables in India. J. Food Process Technol. 6(3): 1-7.
Saeed HA and Hamid HH. 2010. Bacteriological and parasitological assessment of food handlers in the Omdurman Area of Sudan. J. Microbiology Immunol. Infect. 43: 70-73

Sasidharan A and Mathew S. 2011.Current status of fish waste management in Kerala, India A glance at the World. Waste Management 31: 1897-1900

Simko J. 2000. Vermicomposting. Experiment Report Available at: http://www.sawblad essoftware.com (Retrieved on 19th September 2012).

Sydney Fish Market Pty Ltd. 2015. Sound environmental management. Annual Report. Pp: 32-35

World Health Organization. 2019. Health, Hygiene and Sanitation. Http://www.who.int/foodsafety. pp: 45-60. 